\title{
Microgram Per Milliliter Per Milligram Per Kilogram
}

National Cancer Institute

\section{Source}

National Cancer Institute. Microgram Per Milliliter Per Milligram Per Kilogram. NCI

Thesaurus. Code C105473.

A dose calculation unit expressed in microg rams per milliliter, divided by milligram per kilogram. 